\title{
Synchronous Endometrial and Ovarian Cancer in Young Women: Case Report and Review of the Literature
}

\author{
ASKIN DOGAN ${ }^{1}$, BEATE SCHULTHEIS ${ }^{2}$, GÜNTHER A. REZNICZEK ${ }^{1}$, ZIAD HILAL $^{1}$, \\ CEM CETIN $^{1}$, GÜNTHER HÄUSLER ${ }^{3}$ and CLEMENS B. TEMPFER ${ }^{1,3}$ \\ ${ }^{1}$ Department of Obstetrics and Gynecology, Ruhr-Universität Bochum, Bochum, Germany; \\ ${ }^{2}$ Department of Hematology and Oncology, Ruhr-Universität Bochum, Bochum, Germany; \\ ${ }^{3}$ Karl Landsteiner Institute of Gynecological Diagnostics \& Therapy, Mauerbach, Austria
}

\begin{abstract}
Background: Young women with endometrial cancer (EC) have an increased risk of synchronous ovarian cancer. The prognosis of women with synchronous endometrial and ovarian cancer (SEOC) is good. A high proportion of affected women have hereditary non-polyposis colon cancer syndrome (HNPCC). Case presentation: We present the case of a 45-year-old woman with histologically proven endometrioid adenocarcinoma of the endometrium (pT1B, G2, $R O$ without lymphovascular space invasion). She underwent laparoscopic hysterectomy, bilateral salpingo-oophorectomy, and pelvic lymphadenectomy. Final histology revealed a synchronous bilateral endometrioid ovarian cancer ( $p T 1 A, G 2$, RO). HNPCC analysis by immunohistochemistry showed no microsatellite instability in MSH2, MSH6, MLH1, and PMS2. No adjuvant therapy was administered, clinical follow-up with regular gynecological examinations was recommended. In a systematic literature review, 2,904 cases of women with SEOC were identified with 1,035 (36\%) of them being premenopausal or $<50$ years of age. The proportion of women with SEOC among all reported EC cases was 842/23,498 (3\%) and the proportion of young women with SEOC among all reported EC cases was 261/23,498 (1\%). In summary, microsatellite instability and subsequent mutations in mismatch repair genes compatible with HNPCC were identified in 6/15 (40\%) women analyzed.The mean recurrence-free and overall survival times
\end{abstract}

This article is freely accessible online.

Correspondence to: Clemens B. Tempfer, MD, M.B.A., Department of Obstetrics and Gynecology, Ruhr-Universität Bochum, Marien Hospital Herne, Hölkeskampring 40, 44625 Herne, Germany. Tel: +49 23234991801, Fax: +49 23234993393, e-mail: clemens.tempfer@rub.de

Key Words: Ovarian cancer, endometrial cancer, synchronous cancer, HNPCC, young women, cancer syndrome, review. of young women with SEOC were 1.9 ( $\min 0.2$, $\max 3)$ and 4.0 (min 0.2, $\max 22.1$ ) years, respectively. Conclusion: Young women with EC have a high risk of synchronous ovarian cancer. Thus, in young women with EC, bilateral salpingooophorectomy or careful histological assessment of both ovaries are recommended in order to confirm or rule out SEOC. HNPCC testing should be offered to all women.

Endometrial cancer (EC) is the most common female pelvic malignancy with a life-time risk of $4 \%$ (1). It is usually diagnosed at an early stage and has a good prognosis accounting for only $2 \%$ of cancer-related deaths $(1,2)$. The most common age at the time of diagnosis is between 65 and 75 years with a mean age of 69 years (3). However, young women may also be affected by EC. Specifically, around $10 \%$ of women diagnosed with EC are $<50$ years of age with a range of 7 to $20 \%$ reported in the literature (1-4). This subset of women with EC is characterized by an elevated risk of synchronous ovarian cancer and an increased prevalence of hereditary non-polyposis colon cancer syndrome (HNPCC). This has important consequences for the management, prognosis, and genetic counselling of young women with EC.

In the general population of women with EC, synchronous ovarian cancer is a rare finding. In a Surveillance, Epidemiology, and End Results Program (SEER) database analysis of 56986 women with ovarian cancer, for example, Williams et al. identified 1709 (3\%) cases of synchronous endometrial and ovarian cancer (SEOC) (5). Young women with EC, however, have a significantly higher risk of SEOC with a range of 11 to $29 \%$ reported in the literature $(4,6-11)$. The typical histology of SEOC is endometrioid adenocarcinoma in both the endometrium and the ovary, which is found in $>70 \%$ of cases (12). Based on this high rate of histological congruence among SEOC cases, a monoclonal origin has been suggested (13). Specifically, 
Anglesio et al. proposed that the disseminating cells of SEOC may be restricted to physically accessible and microenvironment-compatible sites, i.e. the endometrium and the ovary, with a limited capacity for further dissemination (13). Others have confirmed a high rate of monoclonality among SEOC cases (14).

In case of SEOC, ovarian involvement may be interpreted as metastatic disease or synchronous primary ovarian cancer based on histology and immunohistochemistry. Immunohistochemistry is usually applied to distinguish between an ovarian metastasis of EC and primary ovarian cancer. Endometrioid adenocarcinomas of the endometrium typically express estrogen and progesterone receptors. Other frequently altered genes are KRAS, PTEN, and $\beta$-catenin (15). A subset progresses into high-grade carcinoma which is accompanied by loss of receptor expression and accumulation of TP53 mutations. Low-grade serous carcinoma of the ovary is also associated with KRAS mutations, but in contrast to EC typically expresses mutated BRAF (16). Another useful marker to differentiate between EC and ovarian cancer is PAX-8, because primary ovarian cancer but not EC metastases, express PAX-8 (17). The exact differential diagnosis between an ovarian metastasis and a second primary ovarian cancer, however, is difficult. In the series of Walsh et al., for example, the majority of cases (23/26 [88\%]) were classified as synchronous primaries and only $3 / 26(12 \%)$ were considered ovarian metastases of EC (12). To the contrary, Oranratanaphan et al. diagnosed synchronous primary ovarian cancer in $14 / 63$ (22\%) and ovarian metastases in 49/63 (78\%) cases (4). Akbayir et al. described a 16/28 (57\%) versus 12/28 (43\%) distribution, respectively (7). This discrepancy in the literature underscores the difficulty of distinguishing between ovarian metastasis of EC and a second primary ovarian cancer, especially in cases of two endometrioid adenocarcinoma histologies. These difficulties in the differential diagnosis of SEOC are, however, important, because an exact distinction between ovarian metastasis and primary ovarian cancer has prognostic and therapeutic implications. For example, Oranratanaphan et al. reported a 5-year disease-free survival rate of $64 \%$ compared to $41 \%$ in the synchronous and metastatic groups, respectively and the 5-year overall survival rate was $92 \%$ versus $48 \%$ (4). In addition, patients with EC and metastatic disease in the adnexae would be classified as FIGO stage III cases and thus be eligible for adjuvant platinum-based chemotherapy with or without radiotherapy. On the other hand, patients with an EC and a second primary FIGO stage 1A ovarian cancer would be adequately treated with clinical follow-up alone (18).

Hereditary non-polyposis colon cancer syndrome (HNPCC) is an autosomal dominant genetic syndrome conferring a 85 to $90 \%$ life-time risk of colon cancer, a 40 $60 \%$ life-time risk of EC, and a 6 to $12 \%$ life-time risk of ovarian cancer $(19,20)$. In unselected populations of women with EC, HNPCC is found in 9 to $11 \%$ of women (21). Young women with EC, especially those with SEOC, may even have a higher prevalence of HNPCC, although the exact rate of HNPCC in this subpopulation of women with $\mathrm{EC}$ is unknown.

To highlight the clinical and genetic characteristics, management, and prognosis of young women with SEOC, we report the case of a 45-year-old woman with histologically verified endometrioid adenocarcinoma of the endometrium and synchronous endometrioid ovarian cancer. In addition, we present a systematic review of the literature with case reports and case series of young women with SEOC and discuss common characteristics shared by these women.

\section{Case Report}

We present the case of a 45-year-old woman with histologically verified endometrioid adenocarcinoma of the endometrium and synchronous endometrioid ovarian cancer. In November 2016, the patient was diagnosed with therapyresistant menstrual bleeding disorder. Dilatation and curettage was performed and histology revealed a moderately differentiated endometrioid adenocarcinoma of the endometrium. In December 2016, she underwent total laparoscopic hysterectomy and bilateral salpingooophorectomy. Intraoperative assessment of the depth of infiltration revealed an International Federation of Gynecology and Obstetrics (FIGO) stage 1B EC with tumor invasion into the outer third of the myometrium. Subsequently, staging surgery with laparoscopic pelvic lymphadenectomy was performed in the same session. Intraoperative frozen section analysis of the pelvic lymph nodes showed no evidence of pelvic lymph node metastases. The intraoperative and postoperative course of the patient was uncomplicated. The final histological report confirmed a moderately differentiated endometrioid adenocarcinoma of the endometrium (FIGO pT1B, G2, R0 without lymphovascular space invasion). In addition, a synchronous, bilateral, moderately differentiated endometrioid carcinoma of the ovaries (pT1A, G2, R0) was found. Figure 1 shows hematoxylin-eosin stains of the endometrial and ovarian tumor specimens. Figure 2 shows immunohistochemical studies with estrogen receptor, progesterone receptor, and PAX-8 expression for both tumor specimens. The patient had no family history of colon cancer, EC, breast, or ovarian cancer. HNPCC assessment by immunohistochemistry was performed and showed no microsatellite instability in the MSH2, MSH6, MLH1, and PMS2 proteins (Figure 3). No adjuvant therapy was administered. Follow-up with regular clinical gynecological examinations was recommended. The patient is well and alive without evidence of recurrent disease at the time of this report. 

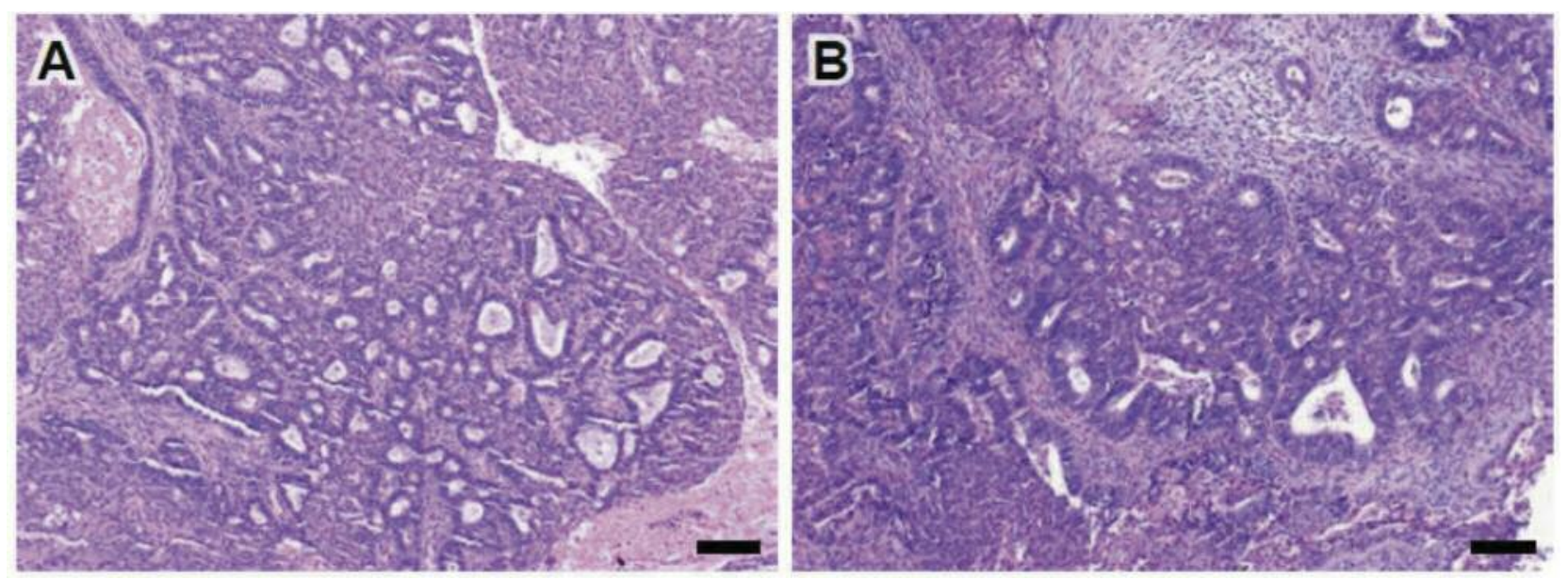

Figure 1. Hematoxylin-eosin stain of an endometrial cancer specimen sampled in 2016 demonstrating endometrioid adenocarcinoma of the endometrium (A) and a synchronous ovarian cancer specimen with endometrioid adenocarcinoma of the ovary (B). Black bar represent $100 \mu \mathrm{m}$.
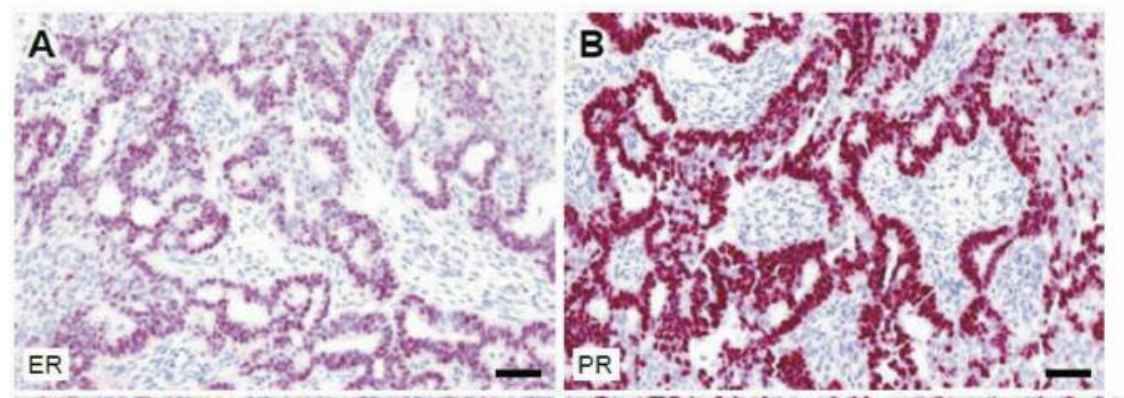

\section{Endometrium (A-B) \\ a}

\section{Ovary (C-E)}
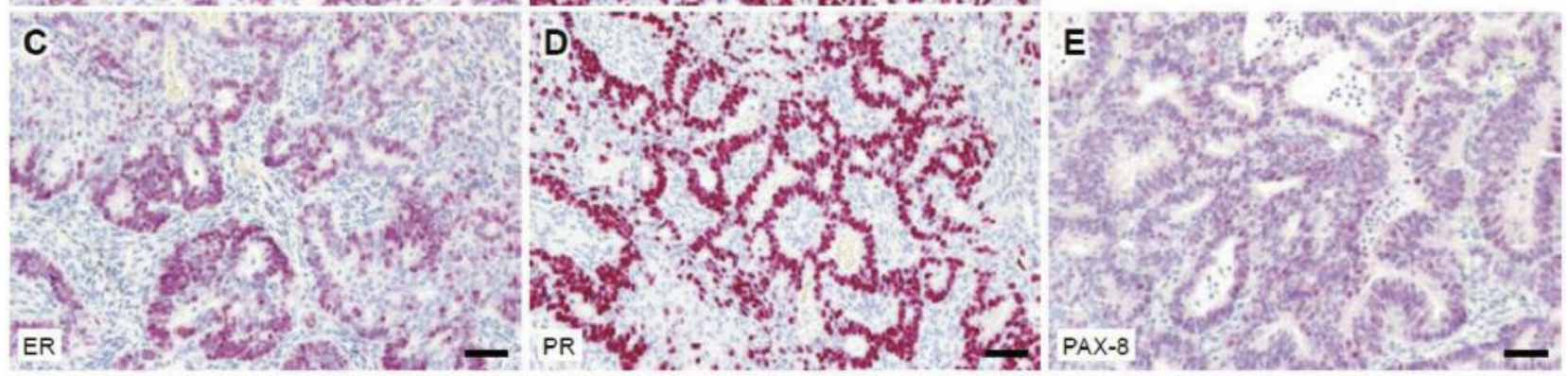

Figure 2. Immunohistochemical stains of an endometrial cancer specimen demonstrating the expression of estrogen receptors (A) progesterone receptors $(B)$ an ovarian cancer specimen demonstrating the expression of estrogen receptors $(C)$, progesterone receptors $(D)$ and PAX-8 $(E)$. Black bars represent $50 \mu \mathrm{m}$.

\section{Literature Review}

In a systematic literature search of the databases PubMed and Cochrane Central Register of Controlled Trials (search date 2312-2016) using the search terms "synchronous[All Fields] AND endometrial[All Fields] AND ("ovarian neoplasms"[MeSH Terms] OR ("ovarian"[All Fields] AND "neoplasms"[All Fields]) OR "ovarian neoplasms"[All Fields] OR ("ovarian"[All Fields] AND "cancer"[All Fields]) OR "ovarian cancer"[All Fields]), we identified 255 studies. After screening all abstracts of these studies, 63 citations were identified reporting on young women with SEOC, defined for the purpose of this review as $<50$ years of age or premenopausal $(4-10,12,13,22-75)$. Studies not reporting on women with SEOC and studies reporting on women with benign ovarian tumors were excluded. Therefore, in summary, 63 studies were retrieved in full and analyzed for this review. Among these studies, we found 16 case reports, 8 retrospective cases series, 38 retrospective cohort studies, and one prospective cohort study. Figure 4 shows a diagram of the literature search. Table I shows the study 

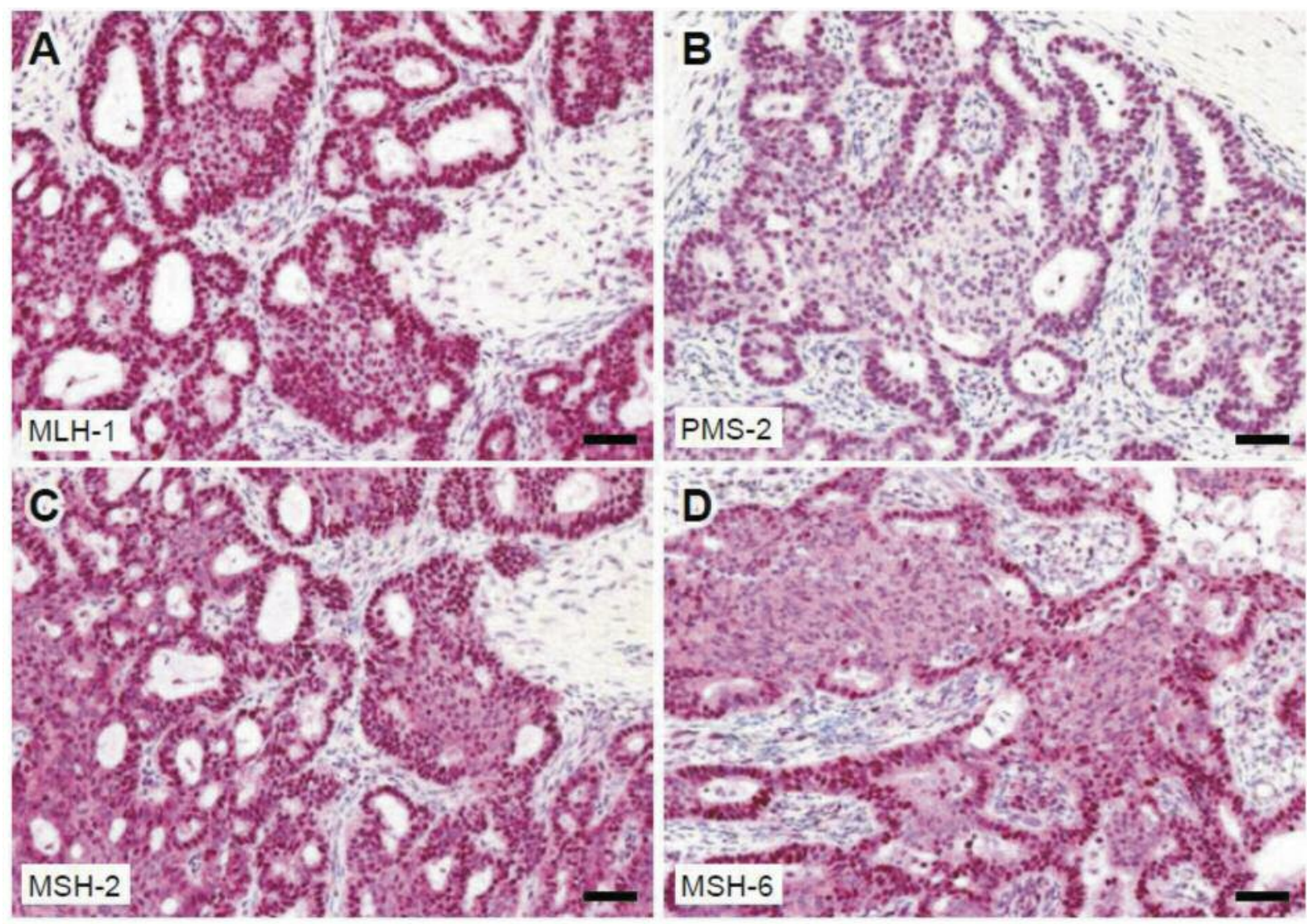

Figure 3. Immunohistochemical stains of an endometrial cancer specimen demonstrating the expression of MLH-1 (A), PMS-2 (B), MSH-2 (C) and MSH-6 (D). Black bars represent $50 \mu \mathrm{m}$.

characteristics and outcomes of patients with SEOC described in all 63 studies. In summary, 2904 women with SEOC were reported with $1035(36 \%)$ of them being premenopausal or $<50$ years of age. In 28 of 63 studies, the number of EC cases, among which women with SEOC were identified, was reported. The proportion of women with SEOC among all reported EC cases was $842 / 23498(3 \%)$ and the proportion of young women with SEOC among all reported EC cases was 261/23498 (1\%). Among women with SEOC, most cases of EC and ovarian cancer were early stage tumors with $72 \%$ of EC cases classified as FIGO stage I disease and $70 \%$ of ovarian cancer cases classified as FIGO stage I disease. The predominant histologic type of SEOC was endometrioid adenocarcinoma in both the endometrium and the ovary. This combination was found in $694 / 1163(60 \%)$ of SEOC cases.

The largest cohort of young women with SEOC was published by Williams et al. (5). In this population-based analysis of the SEER database, the authors identified 530 $(39 \%)$ women $<50$ years of age among a population of 1355 SEOC cases. They compared the prognosis of women with
SEOC and women diagnosed with ovarian cancer alone and found a $25 \%$ reduction in the risk of death. Interestingly, this effect was not only seen in early stage cases, but also in women with late stage cases suggesting a favorable prognosis for SEOC independent of tumor stage. In this study, no separate analysis of young women with SEOC regarding prognosis and stage distribution was performed. The five largest monocentric retrospective cohort studies with more detailed clinical data investigated between 157 (47) and 84 (30) SEOC cases. In these studies, the proportion of young women with SEOC varied considerably with $10 \%$ (9/93) (39), 17\% (21/123) (61), 23\% (36/157) (47), 48\% (30/63) (4), and 51\% (43/84) (30).

The only prospective cohort study recruiting women with SEOC was a Gynecologic Oncology Group (GOG) study published by Zaino et al. (29). In this study, 74 women with SEOC confined to the pelvis were prospectively enrolled, thus ensuring homogenous clinicopathologic characteristics and treatment regimens. A high proportion of women had microscopic spread of tumor in the pelvis or abdomen 


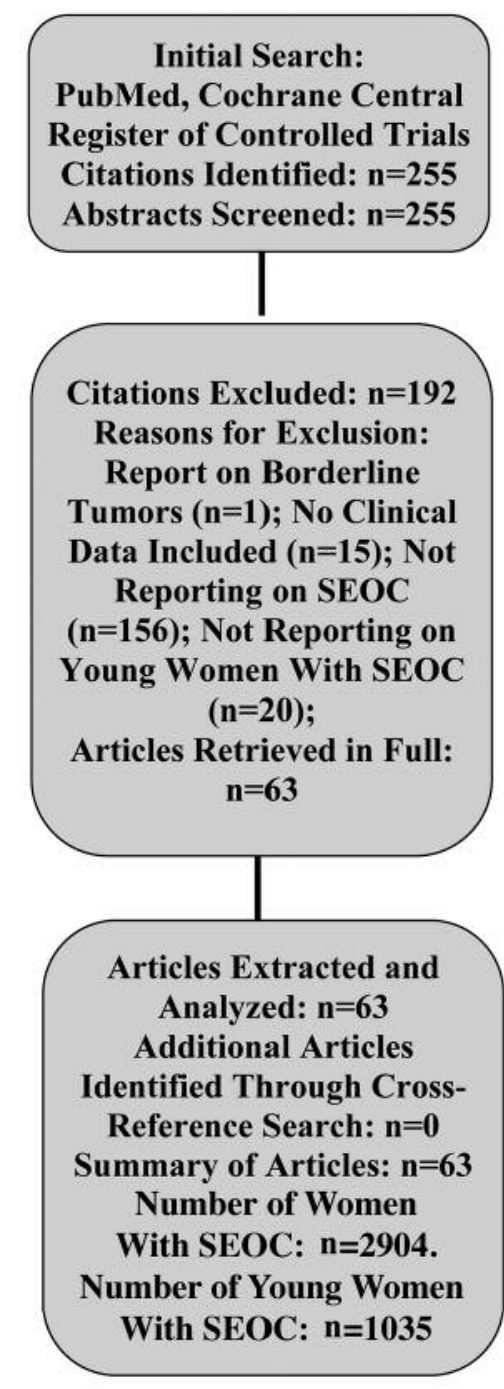

Figure 4. Flow diagram of the literature search algorithm.

$(23 / 74,31 \%)$. Despite this fact, the probability of recurrence after 5 years was only $15 \%$ and the overall probability of surviving 5 and 10 years was $86 \%$ and $80 \%$, respectively. The presence of microscopic metastasis in the pelvis or abdomen, however, discriminated two groups of patients with strikingly different probabilities of recurrence. Specifically, the 5 -year recurrence rate was $27 \%$ for patients with compared to $10 \%$ for patients with microscopic metastases in the pelvis or abdomen.

The bulk of studies identified in this systematic review were retrospective cohort studies with $<50$ patients with SEOC $(6-10,12,22,24,25,28,31,34,37,38,42,44,49$, $51,52,55,56,58,59,61,62,65,67-71)$, cases series of individual patients $(13,23,35,36,43,45,66,73)$, and case reports $(26,27,32,33,41,46,50,53,54,57,60,63,64,72$,
74, 75). As expected, the heterogeneity among these studies with low numbers of patients was high. However, as shown in Table I, most patients had early stage disease of the endometrial and ovarian cancers and the predominant histology was synchronous endometrioid adenocarcinoma.

HNPCC analysis was performed in only 15/2904 young women with SEOC. Microsatellite instability and subsequent mutations in mismatch repair genes were identified among $6 / 15(40 \%)$ of tumors analyzed (Table II). Mutations in the MSH2, MSH6, MLH1, and PMS2 genes were identified in 3, 1,3 , and 1 cases, respectively. Recurrence-free survival time and overall survival time were reported for 7 and 77 young women with SEOC, respectively. The mean recurrence-free survival time was 1.9 ( $\min 0.2, \max 3)$ years and the mean overall survival time was $4.0(\min 0.2, \max 22.1)$ years.

\section{Discussion}

In this case report and review of the literature, we describe a young woman with synchronous endometrioid adenocarcinoma of the endometrium and both ovaries. HNPCC analysis showed no microsatellite instability in MSH2, MSH6, MLH1, and PMS2. We identified 2904 cases of women with SEOC in the literature with 1035 (36\%) of them being premenopausal or $<50$ years of age. HNPCC analysis was only reported for 15 of these women with $6 / 15$ (40\%) demonstrating microsatellite instability and subsequent mutations in mismatch repair genes compatible with HNPCC. These data demonstrate that young women with EC have a high risk of synchronous ovarian cancer and a high proportion of HNPCC. Thus, in young women with EC, bilateral salpingo-oophorectomy or careful histological assessment of both ovaries are recommended in order to confirm or rule out SEOC. HNPCC testing should be offered to all women with SEOC.

Our data are comparable with previously reported studies on young women with SEOC. Based on our analysis, $3 \%$ of women with EC are young, i.e. premenopausal or $<50$ years of age, and a third of these women have SEOC. In accordance, our pooled analysis of the literature identified a proportion of $36 \%$ of young women among all women diagnosed with SEOC. This is compatible with the data of Williams et al. (5). They performed a population-based analysis of 1355 women with SEOC and identified $530 \quad(39 \%)$ cases of premenopausal women (5). Together, these data show that young women with EC have a surprisingly high risk of SEOC. When managing young women with EC, treating physicians should be aware that a third of them will have synchronous ovarian cancer. It seems therefore reasonable to perform bilateral salpingo-oophorectomy or at least careful histological assessment of both ovaries by targeted biopsies in order to confirm or rule out SEOC. 
Table I. Clinical studies describing women with synchronous endometrial and ovarian cancer.

\begin{tabular}{|c|c|c|c|c|c|c|c|c|c|}
\hline Author & Year & $\begin{array}{c}\text { Study } \\
\text { type }\end{array}$ & $\begin{array}{l}\text { Number } \\
\text { of EC } \\
\text { cases }(n)\end{array}$ & $\begin{array}{l}\text { Number } \\
\text { of SEOC } \\
\text { cases }(n)\end{array}$ & $\begin{array}{c}\text { Ovarian/ } \\
\text { metastases 2nd } \\
\text { primary OC (n) }\end{array}$ & $\begin{array}{l}\text { EC FIGO } \\
\text { stage (IA, } \\
\text { IB, II, III+) }\end{array}$ & $\begin{array}{c}\text { OC FIGO } \\
\text { stage (IA-IB, } \\
\text { IC, II, III+) }\end{array}$ & $\begin{array}{l}\text { Histology } \\
\text { (End-End/ } \\
\text { Other) }\end{array}$ & $\begin{array}{l}\text { Number of young } \\
\text { women with } \\
\text { SEOC (n) }\end{array}$ \\
\hline Crissman (8) & 1981 & RCS & 2925 & $6(0.2 \%)^{*}$ & $0 / 6$ & - & - & $4 / 2$ & $6(0.2 \%)$ \\
\hline Zaino (22) & 1984 & RCS & - & 24 & - & $7 / 0 / 14 / 3$ & $12 / 0 / 9 / 3$ & $13 / 11$ & 3 \\
\hline Piura (23) & 1989 & $\mathrm{CS}$ & 156 & $5(3 \%)$ & $0 / 5$ & $4 / 1 / 0 / 0$ & $2 / 1 / 1 / 1$ & $0 / 2$ & $2(1 \%)$ \\
\hline Eisner (24) & 1989 & RCS & 776 & $11(1 \%)$ & $0 / 11$ & $11 / 0 / 0 / 0$ & $7 / 0 / 3 / 1$ & $5 / 6$ & - \\
\hline Sheu (25) & 1995 & RCS & 322 & $6(2 \%)$ & $0 / 6$ & $6 / 0 / 0 / 0$ & $5 / 0 / 0 / 1$ & $3 / 3$ & $2(0.06 \%)$ \\
\hline Gitsch (9) & 1995 & RCS & 254 & $16(6 \%)$ & $0 / 16$ & - & - & - & $5(2 \%)$ \\
\hline Hines (26) & 1995 & $\mathrm{CR}$ & - & 1 & $0 / 1$ & $1 / 0 / 0 / 0$ & $0 / 1 / 0 / 0$ & $1 / 0$ & 1 \\
\hline Lin $(27)$ & 1998 & $\mathrm{CS}$ & - & 10 & $0 / 10$ & $3 / 5 / 1 / 1$ & $2 / 3 / 4 / 1$ & $7 / 3$ & 3 \\
\hline Evans (10) & 1998 & RCS & 289 & $24(8 \%)$ & $1 / 4$ & - & - & - & $5(2 \%)$ \\
\hline Castro (28) & 2000 & RCS & 499 & $18(4 \%)$ & $0 / 18$ & $1 / 9 / 4 / 4$ & $12 / 2 / 3 / 1$ & $1 / 17$ & $3(0.6 \%)$ \\
\hline Zaino (29) & 2001 & PCS & - & 74 & - & $67 / 0 / 7 / 0$ & - & $64 / 10$ & - \\
\hline Soliman (30) & 2004 & RCS & - & 84 & - & $69 / 0 / 8 / 7$ & $69 /-/ 8 / 7$ & $57 / 27$ & 43 \\
\hline Soliman (31) & 2005 & RCS & 1531 & $36(2 \%) * *$ & $0 / 36$ & - & - & $21 / 15$ & $36(2 \%)$ \\
\hline Papathanasiou (32) & 2005 & $\mathrm{CR}$ & - & 1 & $0 / 1$ & $0 / 1 / 0 / 0$ & $1 / 0 / 0 / 0$ & $0 / 1$ & 1 \\
\hline Walsh (12) & 2005 & RCS & - & 26 & $3 / 23$ & $15 / 2 / 4 / 5$ & $6 / 5 / 5 / 10$ & $22 / 4$ & 26 \\
\hline Numnum (33) & 2006 & $\mathrm{CR}$ & - & 1 & $0 / 1$ & $1 / 0 / 0 / 0$ & $0 / 0 / 1 / 0$ & $1 / 0$ & 1 \\
\hline Natee (34) & 2006 & RCS & 644 & $43(7 \%)$ & $0 / 43$ & $29 /-/ 12 / 2$ & $27 /-/ 5 / 11$ & $27 / 16$ & $28(4 \%)$ \\
\hline Tong (35) & 2006 & $\mathrm{CS}$ & 262 & $8(3 \%)$ & $0 / 8$ & $1 / 3 / 2 / 1$ & $2 / 1 / 2 / 3$ & $5 / 3$ & $7(3 \%)$ \\
\hline Lee $(6)$ & 2007 & RCS & 260 & $7(3 \%)$ & $0 / 7$ & $2 / 2 / 1 / 2$ & $4 / 0 / 0 / 3$ & $2 / 5$ & $4(1 \%)$ \\
\hline Phupong (36) & 2007 & $\mathrm{CR}$ & - & 1 & $0 / 1$ & $1 / 0 / 0 / 0$ & $1 / 0 / 0 / 0$ & $0 / 1$ & 1 \\
\hline Caldarella (37) & 2008 & $\mathrm{RCS}$ & 2404 & $46(2 \%)$ & $0 / 46$ & $9 / 18 / 7 / 12$ & - & $21 / 25$ & - \\
\hline Hanprasertpong (38) & 2008 & RCS & - & 7 & $0 / 7$ & $7 / 0 / 0 / 0$ & $1 / 5 / 0 / 1$ & $5 / 2$ & 7 \\
\hline Signorelli (39) & 2008 & RCS & 1550 & $93(6 \%)$ & - & $66 / 7 / 11 / 9$ & $59 / 34 / 0 / 0$ & $72 / 21$ & $9 *$ \\
\hline Ramus (40) & 2008 & RCS & - & 90 & $25 / 39^{\dagger}$ & $40 /-/ 10 / 40$ & $45 /-/ 4 / 41$ & - & - \\
\hline Palma (41) & 2008 & $\mathrm{CR}$ & - & 1 & $0 / 1$ & $1 / 0 / 0 / 0$ & $1 / 0 / 0 / 0$ & $0 / 1$ & 1 \\
\hline Oranratanaphan (4) & 2008 & RCS & 423 & $63(15 \%)$ & $49 / 14$ & $29 / 14 /-/ 20$ & - & - & $30(7 \%)$ \\
\hline Chiang (42) & 2008 & RCS & 844 & $27(3 \%)$ & $0 / 27$ & $25 / 0 / 1 / 1$ & $13 / 6 / 3 / 5$ & $15 / 12$ & $17(2 \%)$ \\
\hline Williams (5) & 2009 & RCS & - & 1355 & - & - & - & - & 530 \\
\hline Garg (43) & 2009 & $\mathrm{CS}$ & $70^{*}$ & $9(13 \%)$ & $0 / 13$ & - & - & $7 / 2$ & $9(13 \%)$ \\
\hline Gungor (44) & 2009 & RCS & - & 11 & - & - & - & $0 / 11$ & 0 \\
\hline Grammatikakis (45) & 2010 & $\mathrm{CS}$ & - & 5 & $0 / 5$ & $5 / 0 / 0 / 0$ & $5 / 0 / 0 / 0$ & $4 / 1$ & - \\
\hline Yang (46) & 2010 & $\mathrm{CR}$ & - & 1 & $0 / 1$ & $1 / 0 / 0 / 0$ & $0 / 1 / 0 / 0$ & $1 / 0$ & 1 \\
\hline Van Niekerk (47) & 2010 & $\mathrm{RCS}$ & - & 157 & $0 / 157$ & - & - & $40 / 117$ & 36 \\
\hline Chen (48) & 2011 & RCS & 818 & $51(6 \%)$ & $33 / 18$ & $25 / 7 / 7 / 12$ & - & $46 / 5$ & $10(1 \%)$ \\
\hline Pan (49) & 2011 & RCS & 976 & $20(2 \%)$ & $17 / 3$ & $9 / 7 / 2 / 2$ & - & $14 / 6$ & $3(0.3 \%)$ \\
\hline Takai (50) & 2011 & $\mathrm{CR}$ & - & 1 & $0 / 1$ & $1 / 0 / 0 / 0$ & $0 / 1 / 0 / 0$ & $1 / 0$ & 1 \\
\hline Eser (51) & 2011 & RCS & 1526 & $43(3 \%)$ & $0 / 43$ & - & - & $29 / 14$ & - \\
\hline $\operatorname{Lim}(52)$ & 2011 & RCS & 920 & $46(5 \%)$ & $0 / 46$ & $32 / 2 / 4 / 8$ & $9 / 18 / 10 / 9$ & $34 / 12$ & $30(3 \%)$ \\
\hline Androutsopoulos (53) & 2011 & $\mathrm{CR}$ & - & 1 & $0 / 1$ & $0 / 1 / 0 / 0$ & 0/0/0/1 & $1 / 0$ & 1 \\
\hline Komiyama (54) & 2012 & $\mathrm{CR}$ & - & 1 & $0 / 1$ & $0 / 1 / 0 / 0$ & $1 / 0 / 0 / 0$ & $0 / 1$ & 1 \\
\hline Yamanoi (55) & 2012 & RCS & 186 & $13(7 \%)$ & $0 / 13$ & $4 / 3 / 4 / 2$ & $1 / 6 / 6 / 0$ & $12 / 1$ & $6(3 \%)$ \\
\hline Juhasz (56) & 2012 & RCS & 251 & $18(7 \%)$ & $0 / 18$ & $15 / 3 / 0 / 0$ & - & - & $6(2 \%)$ \\
\hline Chia (57) & 2012 & $\mathrm{CR}$ & - & 1 & $0 / 1$ & $0 / 0 / 0 / 1$ & $0 / 0 / 0 / 1$ & $0 / 1$ & 1 \\
\hline Akbayir (7) & 2012 & $\mathrm{RCS}$ & 499 & $28(6 \%)$ & $12 / 16$ & $13 / 1 / 1 / 13$ & - & $24 / 4$ & $11(2 \%)$ \\
\hline Rodolakis (58) & 2012 & RCS & - & 30 & $0 / 30$ & $27 /-/ 1 / 2$ & $22 / 0 / 1 / 7$ & $18 / 12$ & 16 \\
\hline Alhilli (59) & 2012 & RCS & 488 & $15(3 \%)$ & $0 / 15$ & $11 / 3 / 1 / 0$ & $7 / 4 / 1 / 3$ & $10 / 5$ & $7(1 \%)$ \\
\hline Atallah (60) & 2013 & $\mathrm{CR}$ & - & 1 & $0 / 1$ & $1 / 0 / 0 / 0$ & $0 / 1 / 0 / 0$ & $1 / 0$ & 1 \\
\hline Song (61) & 2013 & RCS & 3240 & $123(4 \%)$ & - & - & - & - & $21(0.06 \%)$ \\
\hline Liu (62) & 2013 & RCS & - & 43 & $0 / 43$ & $27 /-/ 9 / 7$ & $27 /-/ 4 / 12$ & $12 / 31$ & 26 \\
\hline Bats (63) & 2013 & $\mathrm{CR}$ & - & 1 & $0 / 1$ & $1 / 0 / 0 / 0$ & $0 / 1 / 0 / 0$ & $1 / 0$ & 1 \\
\hline Takatori (64) & 2014 & $\mathrm{CR}$ & - & 1 & $0 / 1$ & $1 / 0 / 0 / 0$ & $0 / 1 / 0 / 0$ & $0 / 1$ & 1 \\
\hline Saatli (65) & 2014 & RCS & - & 20 & $0 / 20$ & $8 / 12 / 0 / 0$ & $7 / 3 / 2 / 8$ & $4 / 16$ & 8 \\
\hline Debska (66) & 2014 & $\mathrm{CS}$ & - & 10 & $0 / 10$ & $3 / 0 / 5 / 2$ & $5 / 0 / 2 / 3$ & $7 / 3$ & 1 \\
\hline Pedroni (75) & 2014 & $\mathrm{CR}$ & - & 1 & $0 / 1$ & - & - & $0 / 1$ & 1 \\
\hline Lin (67) & 2015 & RCS & 759 & $38(5 \%)$ & $15 / 23$ & - & - & - & $13(2 \%)$ \\
\hline Sozen $(68)$ & 2015 & $\mathrm{RCS}$ & - & 50 & - & - & - & $27 / 23$ & 40 \\
\hline Tangjitgamol (69) & 2015 & RCS & 344 & $19(5 \%)$ & $0 / 19$ & - & - & $15 / 4$ & - \\
\hline
\end{tabular}


Table I. Continued

\begin{tabular}{lccccccccc}
\hline Author & Year & $\begin{array}{c}\text { Study } \\
\text { type }\end{array}$ & $\begin{array}{c}\text { Number } \\
\text { of EC } \\
\text { cases (n) }\end{array}$ & $\begin{array}{c}\text { Number } \\
\text { of SEOC } \\
\text { cases (n) }\end{array}$ & $\begin{array}{c}\text { Ovarian/ } \\
\text { metastases 2nd } \\
\text { primary OC (n) }\end{array}$ & $\begin{array}{c}\text { EC FIGO } \\
\text { stage (IA, } \\
\text { IB, II, III+) }\end{array}$ & $\begin{array}{c}\text { OC FIGO } \\
\text { stage (IA-IB, } \\
\text { IC, II, III+) }\end{array}$ & $\begin{array}{c}\text { Histology } \\
\text { (End-End/ } \\
\text { Other) }\end{array}$ & $\begin{array}{c}\text { Number of young } \\
\text { women with } \\
\text { SEOC (n) }\end{array}$ \\
\hline Sadidi (70) & 2015 & RCS & - & 17 & $0 / 17$ & $13 / 0 / 3 / 0$ & $13 / 0 / 0 / 1$ & $14 / 3$ & - \\
Yoo (71) & 2015 & RCS & 282 & $10(3 \%)$ & $0 / 3$ & - & $7 / 0 / 0 / 3$ & - & - \\
Anglesio (13) & 2016 & CS & - & 18 & $7 / 11$ & $16 / 1 / 1 / 0$ & $9 / 7 / 1 / 1$ & $16 / 2$ & 9 \\
Chiofalo (72) & 2016 & CR & - & 1 & $0 / 1$ & $0 / 1 / 0 / 0$ & $1 / 0 / 0 / 0$ & $0 / 1$ & 1 \\
Narin (73) & 2016 & CS & - & 15 & $0 / 15$ & $9 / 6 / 0 / 0$ & $11 / 1 / 3 / 0$ & $9 / 6$ & 10 \\
Kanyilmaz (74) & 2016 & CR & - & 1 & $0 / 1$ & $1 / 0 / 0 / 0$ & $1 / 0 / 0 / 0$ & $1 / 0$ & 1 \\
Pooled Analysis & - & - & 23498 & $842(3 \%)$ & $162 / 880$ & $61 \% / 1 \% /$ & $56 \% / 14 \% /$ & $694 / 469$ & $261(1 \%)$ \\
& & & & & & $12 \% / 16 \%$ & $11 \% / 19 \%$ & & \\
\hline
\end{tabular}

EC, Endometrial cancer; n, number of cases; SEOC, synchronous endometrial and ovarian cancer; OC, ovarian cancer; FIGO, international federation of obstetricians and gynecologists; End, endometrioid; RCS, retrospective cohort study; CR, case report; CS, case series; PCS, prospective cohort study; *only women $<40$ Years; **only women $<50$ years; †26 cases unclassified.

Table II. Clinical studies describing mutational analysis and survival data among young women with synchronous endometrial and ovarian cancer.

\begin{tabular}{|c|c|c|c|c|c|c|c|}
\hline Author & Year & $\begin{array}{l}\text { Number of young } \\
\text { women with } \\
\text { SEOC (n) }\end{array}$ & $\begin{array}{c}\text { Ovarian metastases/ } \\
\text { 2nd primary } \\
\text { OC (n) }\end{array}$ & $\begin{array}{c}\text { HNPCC } \\
\text { present/ } \\
\text { analyzed (n) }\end{array}$ & $\begin{array}{l}\text { Mutated HNPCC- } \\
\text { associated genes } \\
\text { or proteins }\end{array}$ & $\begin{array}{l}\text { Recurrence-free } \\
\text { survival } \\
\text { (y) }\end{array}$ & $\begin{array}{l}\text { Overall } \\
\text { survival } \\
\quad(\mathrm{y})\end{array}$ \\
\hline Zaino (22) & 1984 & 3 & - & - & - & - & 2.9 \\
\hline Piura (23) & 1989 & 2 & $0 / 2$ & - & - & - & 6 \\
\hline Hines (26) & 1995 & 1 & $0 / 1$ & - & - & - & - \\
\hline Soliman (31) & 2005 & 21 & $0 / 21$ & - & - & - & \\
\hline Walsh (12) & 2005 & 26 & $3 / 23$ & - & - & - & 3.2 \\
\hline Numnum (33) & 2006 & 1 & $0 / 1$ & - & - & - & 2 \\
\hline Palma (41) & 2008 & 1 & $0 / 1$ & $1 / 1$ & MSH2 & - & - \\
\hline Hanprasertpong (38) & 2008 & 7 & $0 / 7$ & - & - & - & 4.3 \\
\hline Garg (43) & 2009 & 9 & $0 / 9$ & $1 / 9$ & MSH2, MSH6 & - & - \\
\hline Yang (46) & 2010 & 1 & $0 / 1$ & - & - & 2 & 2 \\
\hline Takai $(50)$ & 2011 & 1 & $0 / 1$ & - & - & 3 & 3 \\
\hline Androutsopoulos (53) & 2011 & 1 & $0 / 1$ & - & & - & 7.4 \\
\hline Yamanoi (55) & 2012 & 6 & $0 / 6$ & - & - & - & 1.9 \\
\hline Juhasz (56) & 2012 & 6 & $0 / 6$ & - & - & - & 1.7 \\
\hline Chia (57) & 2012 & 1 & $0 / 1$ & - & - & - & 0.2 \\
\hline Komiyama (54) & 2012 & 1 & $0 / 1$ & $1 / 1$ & MLH1, MSH2 & 0.25 & 3.7 \\
\hline Alhilli (59) & 2012 & 7 & $0 / 7$ & $1 / 2$ & - & - & 22.1 \\
\hline Atallah (60) & 2013 & 1 & $0 / 1$ & - & & 3 & 3 \\
\hline Bats (63) & 2013 & 1 & $0 / 1$ & $1 / 1$ & MLH1, PMS2 & 0.5 & 0.5 \\
\hline Pedroni (75) & 2014 & 1 & $0 / 1$ & $1 / 1$ & MLH1 & - & 3 \\
\hline Takatori (64) & 2014 & 1 & $0 / 1$ & - & - & - & 2.5 \\
\hline Saatli (65) & 2014 & 8 & $0 / 8$ & - & - & - & 6.2 \\
\hline Debska (66) & 2014 & 1 & $0 / 1$ & - & - & - & - \\
\hline Chiofalo (72) & 2016 & 1 & $0 / 1$ & - & - & 1.5 & 1.5 \\
\hline Kanyilmaz (74) & 2016 & 1 & $0 / 1$ & - & - & 3 & 3.5 \\
\hline Pooled Analysis & - & 110 & $3 / 104$ & $6 / 15$ & - & 1.9 & 4.0 \\
\hline
\end{tabular}

SEOC, Synchronous endometrial and ovarian cancer; n, number of cases; OC, ovarian cancer; EC, endometrial cancer; FIGO, international federation of obstetricians and gynecologists; End, endometrioid; HNPCC, hereditary non-polyposis colon cancer syndrome; RFS, recurrence-free survival; y, years; OS, overall survival.

The typical histology of SEOC is endometrioid adenocarcinoma of both the endometrial and the ovarian tumors, which has been described in up to $70 \%$ of cases (12). Our analysis confirms that the majority of SEOC cases are diagnosed at an early stage and display synchronous endometrioid adenocarcinomas in both endometrium and ovary. Specifically, we found that $72 \%$ of EC cases and $70 \%$ of ovarian cancer cases were classified as FIGO stage I 
disease. Endometrioid adenocarcinoma in both the endometrium and the ovary was found in 694/1163 (60\%) of cases. This unusually early presentation of ovarian cancer, which is otherwise typically diagnosed at a late disease stage, may be interpreted as a chance finding during surgery for EC. An alternative explanation is a possible monoclonal origin of SEOC. For example, Anglesio et al. performed targeted and exome sequencing in 18 women with SEOC and found evidence of a clonal relationship in 17 of them (13). Others have confirmed these findings by subjecting cancer tissue from five SEOC cases to whole-exome massively parallel sequencing, demonstrating that the endometrial and ovarian tumor cells displayed strikingly similar repertoires of somatic mutations and gene copy number alterations in all investigated cases (14). These data suggest that in women with SEOC, the endometrium and the ovary represent microenvironmentcompatible sites with preferential dissemination of tumor cells.

The prognosis of women with SEOC is good based on a high proportion of early stage cases and favorable histologies. In addition to these favorable clinicapthologic characteristics, the prognosis of women with SEOC seems to be better than that of women with single ovarian cancer, independent of tumor stage (5). This may be due to genetically-based restrictions of tumor dissemination in women with SEOC (13). In our analysis of survival data in the literature, the mean recurrence-free survival time of young women with SEOC was 1.9 years and the mean overall survival time was 4.0 years. These survival data underscore that young women with SEOC still have a compromised outcome and guidelinecompatible treatment regarding surgical staging and adjuvant treatment should be applied. In order to optimize the longterm outcome of young women with SEOC, the high risk of HNPCC should be recognized. Our data underscore the strong association of SEOC and HNPCC in young women. Specifically, we found that microsatellite instability and subsequent mutations in mismatch repair genes compatible with HNPCC are present in $40 \%$ of women. This is significantly higher than what has been reported in unselected populations of women with EC, where HNPCC is found in 9$11 \%$ of women (21). Therefore, despite the low number of SEOC patients in the literature analyzed for HNPCC mutations, HNPCC screening in all women with SEOC seems reasonable.

In conclusion, we found that young women with EC have a high risk of synchronous ovarian cancer and a have high risk of HNPCC. Thus, in young women with EC, bilateral salpingooophorectomy or careful histological assessment of both ovaries are recommended in order to confirm or rule out SEOC. HNPCC testing should be offered to all women with SEOC.

\section{Conflicts of Interest}

Authors declare that they have no conflict of interest.

\section{References}

1 Jamison PM, Altekruse SF, Chang JT, Zahn J, Lee R, Noone AM and Barroilhet L: Site-specific factors for cancer of the corpus uteri from SEER registries: collaborative stage data collection system, version 1 and version 2. Cancer 120(Suppl 23): 3836-3845, 2014.

2 Rodriguez AM, Schmeler KM and Kuo YF: Disparities in endometrial cancer outcomes between non-Hispanic White and Hispanic women. Gynecol Oncol 135(3): 525-533, 2014.

3 Robert Koch-Institut (Ed.): Verbreitung von Krebserkrankungen in Deutschland. Entwicklung der Prävalenzen zwischen 1990 und 2010. Beiträge zur Gesundheitsberichterstattung des Bundes. RKI, Berlin, Germany, 2010.

4 Manchana $\mathrm{T}$ and Sirisabya N: Clinicopathologic variables and survival comparison of patients with synchronous endometrial and ovarian cancers versus primary endometrial cancer with ovarian metastasis. Asian Pac J Cancer Prev 9(3): 403-407, 2008.

5 Williams MG, Bandera EV, Demissie $\mathrm{K}$ and RodríguezRodriguez L: Synchronous primary ovarian and endometrial cancers: a population-based assessment of survival. Obstet Gynecol 113(4): 783-789, 2009.

6 Lee TS, Jung JY, Kim JW, Park NH, Song YS, Kang SB and Lee HP: Feasibility of ovarian preservation in patients with early stage endometrial carcinoma. Gynecol Oncol 104(1): 52-57, 2007.

7 Akbayır O, Kuru O, Goksedef P, Numanoglu C, Corbacioglu A and Cetin A: Coexisting ovarian malignancy in patients with clinical stage I endometrial carcinoma. Arch Gynecol Obstet 286(5): 1241-1245, 2012.

8 Crissman JD, Azoury RS, Barnes AE and Schellhas HF: Endometrial carcinoma in women 40 years of age or younger. Obstet Gynecol 57: 699-704, 1981.

9 Gitsch G, Hanzal E, Jensen D and Hacker NF: Endometrial cancer in premenopausal women 45 years and younger. Obstet Gynecol 85: 504-508, 1995.

10 Evans-Metcalf ER, Brooks SE, Reale FR and Baker SP: Profile of women 45 years of age and younger with endometrial cancer. Obstet Gynecol 91: 349-354, 1998.

11 Duska LR, Garrett A, Rueda BR, Haas J, Chang Y and Fuller AF: Endometrial cancer in women 40 years old or younger. Gynecol Oncol 83: 388-393, 2001.

12 Walsh C, Holschneider C, Hoang Y, Tieu K, Karlan B and Cass I: Coexisting ovarian malignancy in young women with endometrial cancer. Obstet Gynecol 106(4): 693-699, 2005.

13 Anglesio MS, Wang YK, Maassen M, Horlings HM, Bashashati A, Senz J, Mackenzie R, Grewal DS, Li-Chang H, Karnezis AN, Sheffield BS, McConechy MK, Kommoss F, Taran FA, Staebler A, Shah SP, Wallwiener D, Brucker S, Gilks CB, Kommoss S and Huntsman DG: Synchronous endometrial and ovarian carcinomas: evidence of clonality. J Natl Cancer Inst 108(6): 428, 2016.

14 Schultheis AM, Ng CK, De Filippo MR, Piscuoglio S, Macedo GS, Gatius S, Perez Mies B, Soslow RA, Lim RS, Viale A, Huberman KH, Palacios JC, Reis-Filho JS, Matias-Guiu X and Weigelt B: Massively parallel sequencing-based clonality analysis of synchronous endometrioid endometrial and ovarian carcinomas. J Natl Cancer Inst 108(6): 427, 2016.

15 Lax SF: Pathology of endometrial carcinoma. Adv Exp Med Biol 943: 75-96, 2017.

16 Ramalingam P: Morphologic, immunophenotypic, and molecular features of epithelial ovarian cancer. Oncology (Williston Park) 30(2): 166-176, 2016. 
17 Goyal A, Masand RP and Roma AA: Value of PAX-8 and SF-1 immunohistochemistry in the distinction between female adnexal tumor of probable wolffian origin and its mimics. Int J Gynecol Pathol 35(2): 167-175, 2016.

18 Johnson N, Bryant A, Miles T, Hogberg T amd Cornes P: Adjuvant chemotherapy for endometrial cancer after hysterectomy. Cochrane Database Syst Rev 10: CD003175, 2011.

19 Schneider R, Schneider C, Kloor M, Fürst A and Möslein G: Lynch syndrome: clinical, pathological, and genetic insights Langenbecks Arch Surg 397(4): 513-525, 2012.

20 Schmeler KM, Lynch HT, Chen LM, Munsell MF, Soliman PT, Clark MB, Daniels MS, White KG, Boyd-Rogers SG, Conrad PG, Yang KY, Rubin MM, Sun CC, Slomovitz BM, Gershenson $\mathrm{DM}$ and $\mathrm{Lu} \mathrm{KH}$ : Prophylactic surgery to reduce the risk of gynecologic cancers in the Lynch syndrome. N Engl J Med 354(3): 261-269, 2006.

21 Batte BA, Bruegl AS, Daniels MS, Ring KL, Dempsey KM, Djordjevic B, Luthra R, Fellman BM, Lu KH and Broaddus RR: Consequences of universal MSI/IHC in screening endometrial cancer patients for Lynch syndrome. Gynecol Oncol 134(2): 319-325, 2014.

22 Zaino R, Whitney C, Brady MF, DeGeest K, Burger RA and Buller RE: Simultaneously detected endometrial and ovarian carcinomas - a prospective clinicopathologic study of 74 cases: A gynecologic oncology group study. Gynecol Oncol 83(2): 355362, 2001

23 Piura B and Glezerman M: Synchronous carcinomas of endometrium and ovary. Gynecol Oncol 33(2): 261-264, 1989.

24 Eisner RF, Nieberg RK and Berek JS: Synchronous primary neoplasms of the female reproductive tract. Gynecol Oncol 33(3): 335-339, 1989.

25 Sheu BC, Lin HH, Chen CK, Chao KH, Shun CT and Huang SC: Synchronous primary carcinomas of the endometrium and ovary. Int J Gynaecol Obstet 51(2): 141-146, 1995.

26 Hines JF, Tucker A, Grendys EC, Ascher SM and Barter JF: Spontaneous preoperative internal jugular and subclavian vein thrombosis associated with an early-stage synchronous ovarian/ endometrial malignancy. Gynecol Oncol 56(2): 298301, 1995.

27 Lin WM, Forgacs E, Warshal DP, Yeh IT, Martin JS, Ashfaq R and Muller CY: Loss of heterozygosity and mutational analysis of the PTEN/MMAC1 gene in synchronous endometrial and ovarian carcinomas. Clin Cancer Res 4(11): 2577-2583, 1998.

28 Castro IM, Connell PP, Waggoner S, Rotmensch J and Mundt AJ: Synchronous ovarian and endometrial malignancies. Am J Clin Oncol 23(5): 521-525, 2000.

29 Zaino RJ, Unger ER and Whitney C: Synchronous carcinomas of the uterine corpus and ovary. Gynecol Oncol 19(3): 329-335, 1984.

30 Soliman PT, Slomovitz BM, Broaddus RR, Sun CC, Oh JC, Eifel PJ, Gershenson DM and Lu KH: Synchronous primary cancers of the endometrium and ovary: a single institution review of 84 cases. Gynecol Oncol 94(2): 456-462, 2004.

31 Soliman PT, Broaddus RR, Schmeler KM, Daniels MS, Gonzalez D, Slomovitz BM, Gershenson DM and Lu KH: Women with synchronous primary cancers of the endometrium and ovary: do they have Lynch syndrome? J Clin Oncol 23(36): 9344-9350, 2005.

32 Papathanasiou K, Tolikas A, Dovas D, Kostopoulou E, Fragkedakis N and Tzafettas J: Simultaneously detected primary malignant tumors of ovary and endometrium with unusual histology. Int J Gynecol Cancer 15(6): 1191-1194, 2005.
33 Numnum TM, Leath CA 3rd and Straughn MJ Jr.: Synchronous primary endometrial and ovarian carcinoma in a patient with marantic endocarditis. Obstet Gynecol 108(3 Pt 2): 748-750, 2006.

34 Natee J, Kietpeerakool C, Srisomboon J, Khunamornpong S, Suprasert P, Phongnarisorn C, Cheewakriangkrai C, Charoenkwan $\mathrm{K}$, Siriaree $\mathrm{S}$ and Pantusart A: Clinicopathologic analysis of women with synchronous primary carcinomas of the endometrium and ovary: 10- year experience from Chiang Mai University Hospital. Asian Pac J Cancer Prev 7(2): 234-238, 2006.

35 Tong SY, Lee YS, Park JS, Bae SN, Lee JM and Namkoong SE: Clinical analysis of synchronous primary neoplasms of the female reproductive tract. Eur J Obstet Gynecol Reprod Biol 136(1):78-82, 2008.

36 Phupong V, Khemapech $\mathrm{N}$ and Triratanachat S: Triple synchronous primary cervical, endometrial and ovarian cancer with four different histologic patterns. Arch Gynecol Obstet 276(6): 655-658, 2007.

37 Caldarella A, Crocetti E, Taddei GL and Paci E: Coexisting endometrial and ovarian carcinomas: a retrospective clinicopathological study. Pathol Res Pract 204(9): 643-648, 2008.

38 Hanprasertpong J, Sakolprakraikij S and Geater A: Endometrial cancer in Thai women aged 45 years or younger. Asian Pac J Cancer Prev 9(1): 58-62, 2008.

39 Signorelli M, Fruscio R, Lissoni AA, Pirovano C, Perego P and Mangioni C: Synchronous early-stage endometrial and ovarian cancer. Int J Gynaecol Obstet 102(1): 34-38, 2008.

40 Ramus SJ, Elmasry K, Luo Z, Gammerman A, Lu K, Ayhan A, Singh N, McCluggage WG, Jacobs IJ, Whittaker JC and Gayther SA: Predicting clinical outcome in patients diagnosed with synchronous ovarian and endometrial cancer. Clin Cancer Res 14(18): 5840-5848, 2008.

41 Palma L, Marcus V, Gilbert L, Chong G and Foulkes WD: Synchronous occult cancers of the endometrium and fallopian tube in an $\mathrm{MSH} 2$ mutation carrier at time of prophylactic surgery. Gynecol Oncol 111(3): 575-578, 2008.

42 Chiang YC, Chen CA, Huang CY, Hsieh CY and Cheng WF: Synchronous primary cancers of the endometrium and ovary. Int J Gynecol Cancer 18(1): 159-164, 2008.

43 Garg K, Shih K, Barakat R, Zhou Q, Iasonos A and Soslow RA: Endometrial carcinomas in women aged 40 years and younger: tumors associated with loss of DNA mismatch repair proteins comprise a distinct clinicopathologic subset. Am J Surg Pathol 33(12): 1869-1877, 2009.

44 Gungor T, Kanat-Pektas M, Ustunyurt E and Mollamahmutoglu L: Synchronous primary tumors of the female genital tract: a single center experience. Arch Gynecol Obstet 279(5): 667-672, 2009.

45 Grammatikakis I, Zervoudis S, Evangelinakis N and Tziortzioti V: Endometrium and ovarian cancer synchronous to endometriosis - a retrospective study of our experience of 7 years. J Med Life 3(1): 76-79, 2010.

46 Yang YH, Chen RJ, Lin MC, Cheng SP and Chang TC: Synchronous primary ovarian and endometrial cancer with a fair prognosis in a young woman. Taiwan J Obstet Gynecol 49(1): 97-100, 2010

47 van Niekerk CC, Bulten J, Vooijs GP and Verbeek AL: The association between primary endometrioid carcinoma of the ovary and synchronous malignancy of the endometrium. Obstet Gynecol Int 2010: 465162, 2010.

48 Chen L, Zhao Q and Lv X: Characteristics and prognosis of coexisting adnexa malignancy with endometrial cancer: a single 
institution review of 51 cases. Arch Gynecol Obstet 283(5): 1133-1137, 2011.

49 Pan Z, Wang X, Zhang X, Chen X and Xie X: Retrospective analysis on coexisting ovarian cancer in 976 patients with clinical stage I endometrial carcinoma. J Obstet Gynaecol Res 37(4): 352-358, 2011.

50 Takai N, Kai K, Tsuno A, Nasu K, Kashima K and Narahara H: Synchronous ovarian endometrioid adenocarcinoma with a functioning stroma and endometrial endometrioid adenocarcinoma by different loss of heterozygosity findings. Arch Gynecol Obstet 284(4): 951-955, 2011.

51 Eser S, Gulhan I, Özdemir R, Dicle N, Hanhan M, Baloglu A, Ozsaran A and Saygili U: Synchronous primary cancers of the female reproductive tract in Turkish women. Asian Pac J Cancer Prev 12(4): 857-859, 2011.

52 Lim YK, Padma R, Foo L, Chia YN, Yam P, Chia J, Khoo-Tan H, Yap SP and Yeo R: Survival outcome of women with synchronous cancers of endometrium and ovary: a 10 year retrospective cohort study. J Gynecol Oncol 22(4): 239-243, 2011.

53 Androutsopoulos G, Adonakis G, Tsamandas A, Andonopoulos A and Decavalas G: Systemic sclerosis and multiple cancers of the female genital tract: prolonged survival following current treatment strategies. Case Rep Rheumatol 2011: 392068, 2011.

54 Komiyama S, Nishio E, Ichikawa R, Miyamura H, Kawamura $\mathrm{K}$, Komiyama M, Nishio $\mathrm{Y}$ and Udagawa $\mathrm{Y}$ : Asymptomatic synchronous quintuple primary cancers. Gynecol Obstet Invest 74(4): 324-328, 2012.

55 Yamanoi K, Mandai M, Suzuki A, Matsumura N, Baba T, Yoshioka Y, Kosaka K and Konishi I: Synchronous primary corpus and ovarian cancer: High incidence of endometriosis and thrombosis. Oncol Lett 4(3): 375-380, 2012.

56 Juhasz-Böss I, Fehm T, Becker S, Rothmund R, Krämer B, Staebler A, Wallwiener D and Solomayer EF: Endometrial cancer: comparison of patients with synchronous primary carcinoma of the endometrium and ovary vs. endometrial carcinoma with ovarian metastases. Geburtshilfe Frauenheilkd 72(8): 721-726, 2012.

57 Chia CC and Huang SC: Rapid progression of synchronous ovarian and endometrial cancers with massive omental carcinomatosis. Taiwan J Obstet Gynecol 51(3): 452-454, 2012.

58 Rodolakis A, Thomakos N, Akrivos N, Sotiropoulou M, Ioannidis I, Haidopoulos D, Vlachos G and Antsaklis A: Clinicopathologic insight of simultaneously detected primary endometrial and ovarian carcinomas. Arch Gynecol Obstet 285(3): 817-821, 2012.

59 AlHilli MM, Dowdy SC, Weaver AL, St Sauver JL, Keeney GL, Mariani A, Podratz KC and Bakkum-Gamez JN: Incidence and factors associated with synchronous ovarian and endometrial cancer: a population-based case-control study. Gynecol Oncol 125(1): 109-113, 2012.

60 Atallah D, Safi J, El Kassis N, Rouzier R and Chahine G: Simultaneous early ovarian and endometrial cancer treated conservatively with spontaneous pregnancy. J Ovarian Res 6: 59, 2013.

61 Song T, Seong SJ, Bae DS, Suh DH, Kim DY, Lee KH, Lim MC and Lee TS: Synchronous primary cancers of the endometrium and ovary in young women: a Korean Gynecologic Oncology Group Study. Gynecol Oncol 131(3): 624-628, 2013.

$62 \mathrm{Liu} \mathrm{Y,} \mathrm{Li} \mathrm{J,} \mathrm{Jin} \mathrm{H,} \mathrm{Lu} \mathrm{Y} \mathrm{and} \mathrm{Lu} \mathrm{X:} \mathrm{Clinicopathological}$ characteristics of patients with synchronous primary endometrial and ovarian cancers: A review of 43 cases. Oncol Lett 5(1): 267270,2013
63 Bats AS, Roussel H, Narjoz C, Le Frere-Belda MA, Chamming's F, Blons H, Laurent-Puig P and Lecuru F: Microsatellite instability analysis for the screening of synchronous endometrial and ovarian cancer in Lynch syndrome. Anticancer Res 33(9): 3977-3981, 2013.

64 Takatori E, Shoji T, Miura Y, Takeuchi S, Uesugi N, and Sugiyama T: Triple simultaneous primary invasive gynecological malignancies: a case report. J Obstet Gynaecol Res 40(2): 627631, 2014.

65 Saatli B, Yildirim N, Ozay AC, Koyuncuoglu M, Demirkan B and Saygili U: Synchronous tumors of the female genital tract: a 20year experience in a single center. Ginekol Pol 85(6): 441-445, 2014.

66 Dębska-Szmich S, Czernek U, Krakowska M, Frąckowiak M, Zięba A, Czyżykowski R, Kulejewska D and Potemski P: Synchronous primary ovarian and endometrial cancers: a series of cases and a review of literature. Prz Menopauzalny 13(1): 64-69, 2014.

67 Lin KY, Miller DS, Bailey AA, Andrews SJ, Kehoe SM, Richardson DL and Lea JS: Ovarian involvement in endometrioid adenocarcinoma of uterus. Gynecol Oncol 138(3): 532-535, 2015.

68 Sozen H, Vatansever D, Iyibozkurt AC, Topuz S, Ozsurmeli M, Salihoglu Y, Guzelbey B and Berkman S: Clinicopathologic and survival analyses of synchronous primary endometrial and epithelial ovarian cancers. J Obstet Gynaecol Res 41(11): 1813-1819, 2015.

69 Tangjitgamol S, Khunnarong $\mathrm{J}$ and Srijaipracharoen S: Synchronous and metachronous malignancy in endometrial cancer patients treated in a tertiary care center of Thailand. J Gynecol Oncol 26(4): 293-302, 2015.

70 Sadidi H, Izadi-Mood N, Sarmadi S, Yarandi F, AminiMoghaddam S, Esfahani $F$ and Sadidi M: Comparison of clinicopathologic variables in coexistence cancers of the endometrium and ovary: A review of 55 cases in an academic center in Iran. J Res Med Sci 20(8): 727-732, 2015.

71 Yoo HJ, Lim MC, Son Y, Seo SS, Kang S, Kim SH, Yoo CW and Park SY: Survival outcome in endometrial cancer patients according to hereditary predisposition. Taiwan J Obstet Gynecol 54(1): 24-28, 2015.

72 Chiofalo B, Di Giuseppe J, Alessandrini L, Perin T, Giorda G, Canzonieri $\mathrm{V}$ and Sopracordevole F: Triple synchronous invasive malignancies of the female genital tract in a patient with a history of leukemia: A case report and review of the literature. Pathol Res Pract 212(6): 573-577, 2016.

73 Narin MA, Karalok A, Basaran D, Ureyen I, Turkmen O, Turan T and Tulunay G: Does synchronous endometrioid endometrial cancer have any prognostic effect on Stage I endometrioid ovarian cancer? Eur J Obstet Gynecol Reprod Biol 200: 113-116, 2016.

74 Kanyilmaz G, Aktan M, Koc M and Findik S: Cutaneous metastases of the synchronous primary endometrial and bilateral ovarian cancer: an infrequent presentation and literature review. Case Rep Oncol Med 2016: 4568653, 2016.

75 Pedroni M, Di Gregorio C, Cortesi L, Reggiani Bonetti L, Magnani G, Simone ML, Medici V, Priore Oliva C, Marino M and Ponz de Leon M: Double heterozygosity for BRCA1 and hMLH1 gene mutations in a 46-year-old woman with five primary tumors. Tech Coloproctol 18(3): 285-289, 2014.

Received January 10, 2017

Revised February 12, 2017 Accepted February 20, 2017 